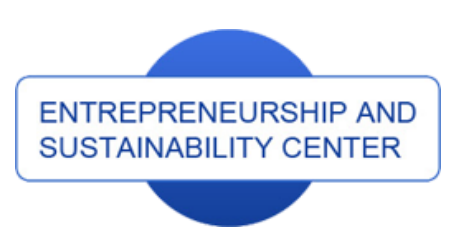

Publisher

http://jssidoi.org/esc/home

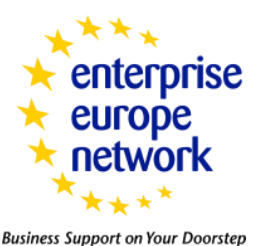

Business Support on Your Doorstep

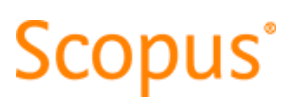

\title{
STATE AID AND INVESTMENT: CASE OF SLOVAKIA*
}

\author{
Michal Fabuš $\check{1}^{\text {, Marek Csabay }}{ }^{2}$ \\ ${ }^{1}$ School of Economics and Management in Public Administration in Bratislava, Furdekova 16, Bratislava, 851 04, Slovak \\ Republic
}

${ }^{2}$ Pan-European university, Faculty of Economics, Tematinska 10, Bratislava, 851 05, Slovak Republic

E-mails: $\underline{{ }^{1} \text { michal.fabus@vsemvs.sk; }{ }^{2} \text { marek.csabay@paneurouni.com }}$

Received 10 May 2018; accepted 10 August 2018; published 30 September 2018

\begin{abstract}
State investment incentives are detrimental to the quality of the business environment and create unequal starting conditions for entrepreneurs to implement investment plans. In some cases, however, it is necessary to regulate the allocation of inward investment to regions within one country and thus decrease the disparities. Investment incentives are instruments that in general might violate market principles and thus are regulated within the EU internal market. Despite being aware of this fact most economists and politicians advocate these kinds of measures as necessary and relatively cheap in order to push the economy forward or win international big private equity investments. Investment aid is regional aid to stimulate investment in disadvantaged regions and to create new jobs in the Slovak Republic. Beneficiaries of this assistance may be natural and legal persons authorized to carry on business in the territory of the Slovak Republic and whose investment activities and projects meet the conditions of Act no. 561/2007 Z.z. on Investment Assistance and on Amendments to Certain Acts. This paper will focus on how investment incentive attracts foreign investment in the Slovak Republic and based on the data from 2002 to 2017 we will analyze their effectiveness on the created jobs. Despite the possible support from the Slovak government not all foreign investors areapplying for investment incentives, either are in contact with the government during their investment phase.
\end{abstract}

Keywords: investments incentives; stare aid; foreign direct investmnets; economic growth

Reference to this paper should be made as follows: Fabuš, M.; Csabay, M. 2018. State aid and investment: case of Slovakia, Entrepreneurship and Sustainability Issues 6(2): 480-488. http://doi.org/10.9770/jesi.2018.6.2(1)

JEL Classifications: E22, F21, F43

\footnotetext{
* The paper is the output of an international scientific project IGA no. 2/2018 - M „Problems and Suggestions - Comparison of Commercial Enviroment between China - Slovakia and Facilitation of Trade and Investment". (Funder: VSEMvs IGA VSEMvs, i.e. School of Economics and Management in Public Administration)
} 


\section{Introduction}

Foreign investment is a recognized element in the economy of the state, serving on the one hand to reduce unemployment and, on the other hand, playing an important role in the inflow of the vast amount of capital it spends in the interests of state welfare, often presented primarily for the benefit of the public and for the citizens. Foreign Direct Investment (FDI) is a direct investment in a business from another country. They are usually in a form either of a share acquisition of an investor in another company abroad or a creation of a new totally owned company abroad, unlike portfolio investments in financial markets. FDI must usually be at least $10 \%$ of the company's share (purchase of shares or other business share). The investor gains significant decision-making power in the company where he invests. FDI are long-term assets such as land, buildings, machinery and equipment acquired in the country by foreign legal or natural persons and, on the other hand, by domestic physical or legal entities abroad. If there is a rapid influx of FDI in the country, it means that the business environment represents a healthier rate of return on investment and labor productivity is higher than in other countries.

FDI are a global phenomenon whose share in international business is steadily rising and generates large capital injections. FDI has been and continues to be an important factor in the development of transition countries. They help create new jobs, which can lead to an influx of new technologies, and in total they provide the necessary capital to restore a successful transition to the market economy. However, a one-sided focus on the inflow of FDI also brings some negatives. First, the high share of foreign investors in the domestic market is exposed to structural problems that may occur when investors leave. At present, the major player in foreign direct investment is transnational corporations, whose business in many countries allows them to move profits from one market to another, often due to more favorable tax conditions.

The issue of investment attractiveness determinants is currently a topic often dealt with in many publications of both Slovak and foreign authors. The significance of factors affecting investment attractiveness is dealt with for instance by A. Bevan (2000, 2004), S. Estrin (2000, 2004), J. Pietrucha et al. (2018) and K. Meyer (2004), who divide these factors into two basic groups (political and economic factors) and differentiate between factors affecting host and domestic economies. S. Brakman and H. Garretsen (2008) seek the main reasons leading companies to foreign investments as well as ways how a foreign market can be entered. Other authors (e.g. Dudáš 2004, 2010; Fabuš 2010, 2011, 2012, 2014; Korauš et al. 2018; Tvaronavičienė, 2018) deal with individual factors and their impact on economic development, respectively economic growth, and motivation of investors, economic and political conditions created in a host country. Theoretical background of investment attractiveness and the theories of creation, respectively motivation of FDI creation and movement were based on leading foreign authors. The best known is J. H. Dunning $(1979,2001)$ and his eclectic theory based on three categories of factors shaping the decision-making of investors. Dunning introduced a well-known OLI paradigm and motives which are essential in decision-making on investment, like advantages resulting from ownership and ownership rights, advantages resulting from information on human resources and new information and specific advantages resulting from a locality (Dunning, 1979, 2001). S. A. Hymer (1976) is concerned with why companies transfer intermediate products (knowledge, technologies, etc.) among countries. He also opines that FDI can be clarified by foreign control. As far as Slovak authors are concerned, we can mention J. Táncošová (2012, 2013, 2014), S. Ferenčíková (2005) and K. Belanová (2014), who analyse determinants and location, and their significance in relation to an access to FDI, and T. Dudáš (2010), who deals with the significance of workforce and S. Švecová (2012), who deals with the role of education in the structure of employees and advancement so that they fulfil market requirements on workforce.

This paper deals with investment incentive attraction of foreign investment in the Slovak Republic and based on the data from 2002 to 2017 we will analyze their effectiveness on the created jobs. We use standard scientific 
methods such as analysis, synthesis, comparison, etc. The paper is structured into integral parts dealing with development of FDI in Slovak republic and investment incentives based on current data, their mutual comparison and their relationship with the concluded conclusion.

\section{Investments in Slovakia}

One of the major benefits of FDI is the source of capital in areas where there is a lack of domestic investment and therefore a lowering standard of living or increasing regional disparities. FDI capital is of a long-term nature, which is crucial to the proper development of the country. Transnational investors have a large reach and are therefore able to source resources on more favorable terms than domestic companies. The investment environment is mostly but not exclusively influenced by legal standards, economic rules and political relations in the country (Nazarczuk, Krajewska, 2018). The environment can be constantly changing and that is why new natural investment opportunities are being constantly created for potential investors as well as for existing businesses (Cheba, Szopik-Depczyńska, 2017; Korcsmáros, Šimova 2018).

Slovakia is today one of the most attractive countries for business and investment in Europe based e.g. on the number of expansions of already existing investments in recent years. It is a young country and is strategically located in the heart of Europe. Slovakia has been a member of NATO and EU since 2004. It is now a truly liberal democracy with a functioning market economy and legislation that is fully harmonized with the EU. The Slovak economy grew further in 2016, mainly thanks to strong net exports and acceleration in household consumption. Economic activity is projected to continue to grow steadily over the forecast horizon and provide further support for the labor market through permanent job creation. According to EUROSTAT, inflation in 2017 after three years of decline in consumer prices will show positive growth. Increased food and service prices will become the main driver of overall return on prices, which will allow CPI inflation to increase to $0.9 \%$ in 2017 . The government deficit is projected to decline gradually.

Development of FDI inflows in Slovakia from 1993 until 2000 had low value, few investors were coming to our territory. During this period, Slovakia has not used its potential to attract foreign investors. Entry of foreign capital into the economy didn't match the demand for foreign direct investors. Slovakia lagged mainly due to political and economic weaknesses which are a threat to investors while investing. In the years 2000-2008 the situation changed rapidly in the inflow of FDI into Slovakia, see Figure 1. The program of the new government was focused mainly on increasing FDI inflows, implement measures to meet this objective. In 2008 crises began on international financial markets due to problems of mortgages in the US, which escalated into a global financial crisis, which was reflected in the amount of global flows of FDI. 


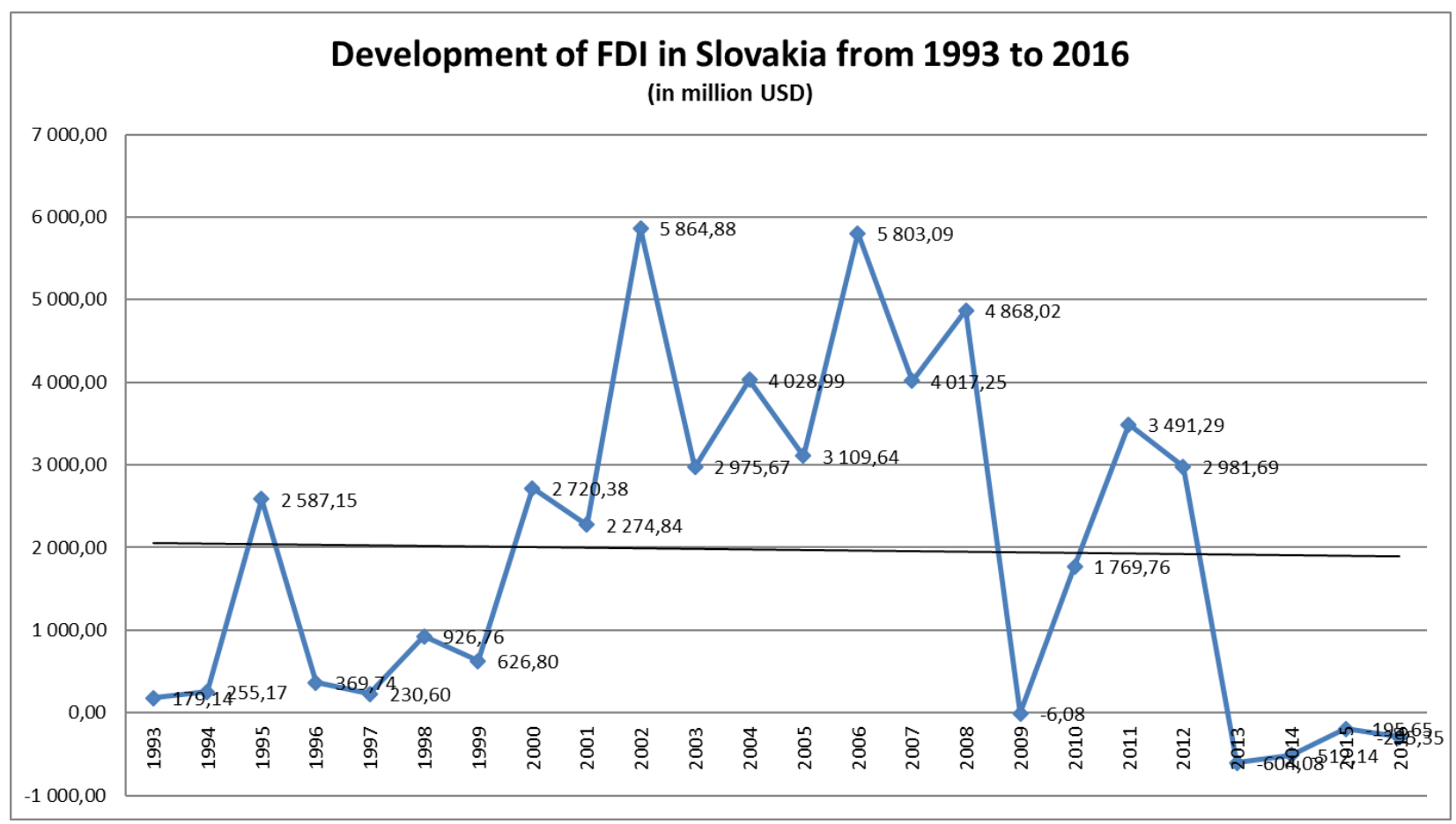

Fig.1. Development of FDI in Slovakia from 1993 to 2016

Source: Own processing according to UNCTAD data

The global economic and financial crisis had a severe effect on FDI flows around the world. Having peaked in 2007, EU-27 FDI flows dropped sharply in 2008. Slovakia suffered same development which became significant in 2009. Fortunately, this decline was recorded only in 2009 and since 2010 inflow of FDI slowly continued until 2013. Between the years 2013 and 2014 Slovakia suffered FDI inflow drop again with even more significant FDI outflow in this period. In 2015 Slovakia recorded slow increase of FDI inflows, with prospects for further growth in near future (new investors announced their investment plans in Slovakia), like Jaguar Land Rover in 20162017. This drop was caused by intracompany financial flows (which are considered also FDI), where the companies started to return intracompany loans. Also, there was for almost a year, the State aid scheme was not in place, which influenced the flows.

In Slovakia, the differences between FDI status and FDI inflows in the regions are significantly different, especially between East and West (Gozora, 2014). Western regions have received approximately $3 / 4$ of the total FDI that they have directed to our country, which means that the regions of Central and Eastern Slovakia are lagging. FDI inflows and FDI are largely dominated by the Bratislava Region, which accounted for $64.85 \%$ of total FDI over the period 2009-2015, which is comparable to the period 1993-2007 when it was up to 67.6\%.

These figures clearly show that Slovakia, even after years, is divided into "rich west and poor east", which is being slowly counterbalanced with latest investments of 2017 and 2018 coming to the region of Košice and other in the East of the country. Secondly, with a significant decrease of Trnava region with a total of 12.30\% (based mostly on intracompanies financial flows), followed by Trenčiansky with $10.47 \%$, Nitra region with $8.48 \%$ improved compared to the period 1993-2007 when he gained just over 3,1\%. The region of Zilina has gained 9.38\% and Prešovský 8\%, which is a jump of almost 7\% in the period 1993-2007. The big fall is significant in Košice, where even FDI drops to $-10.87 \%$, as is the case for Banska Bystrica region, which recorded -2.61 FDI 
decline, which compared to 1993-2007 shows a difference when Kosice gained 8.8\% and was on the second in the FDI inflow and Bansko Bystrický with $1.9 \%$ placed in the penultimate place.

As we mentioned in the end of the list of regions are the Košice and Banska Bystrica region, where at least FDI was invested, caused significant differences in employment, causing a high fluctuation which leads to low wages and the transfer of the population to the richer regions or abroad. In cuch cases the question of investment incentives, despite being an undue interference with the economy, are justified.

From the beginning of the economic crisis until the end of 2016 there was no new big foreign investor in Slovakia that would employ at least 500 employees. Only in 2017 the construction of Jaguar Land Rover in Nitra began, but production has not started yet. Or Amazon, who also announced investments in recent time. The state could help investors in particular simplifying tax rules on the labor market, eliminating corruption and bureaucracy.

\section{State Aid - Investment incentives in Slovakia}

Investment incentives are undoubtedly a serious argument for the benefit of the Slovak Republic. As an EU member country, however, the Slovak Republic must ensure compliance with EU rules. One of the fundamental principles of EU law is to promote competition in the EU internal market. Therefore, it is forbidden by the EU Member States to provide any incentives that could distort competition and affect trade between Member States. The state aid concept is very broad and covers a wide range of direct and indirect public incentives, but as a theoretical or legislative topic is not of our interest within this article. Investment incentives that seek to attract foreign investors are therefore a priori considered to distort competition. The Slovak Republic has marked regional differences and investment incentives are one of the tools to motivate investors to place their new operations on a priority basis in less developed regions, in areas with higher unemployment rates. The positive impact of the new investment should be reflected in the creation of new jobs, opportunities for graduate employment, and the creation of new entrepreneurial opportunities for local companies. Binding to a particular region is one of the fundamental features of investment incentives and their provision should be supported not only by foreign but also domestic entrepreneurs.

Investment aid may be provided in the form of:

- grants for long-term tangible assets and intangible fixed assets;

- income tax relief;

- contribution to created new jobs;

- the transfer of immovable property or the letting of immovable property at a value lower than the value of the immovable property or the value of the rental of immovable property determined by expert opinion.

Investment projects that can be supported in Slovakia are divided into four categories, namely industry, tourism, technology centers and strategic services centers. Costs for procurement of land, buildings, new technological and machinery equipment, intangible fixed assets - licenses, patents, or wage costs of newly created jobs over a 2-year period are considered eligible costs. Terms for technology centers and strategic services centers are the same for all districts, the minimum investment amount must be $€ 500$ thousand, respectively $€ 400$ thousand. In the case of industrial projects, the minimum investment depends on the unemployment rate in the district, at least 40 jobs must be created and, in the case of established enterprises, the production of min. by $15 \%$. The maximum amount of investment aid is the maximum share of the eligible costs that may be approved by the investor in the form of investment aid. It is based on GDP per capita in the region. All regions except Bratislava are eligible; in Western Slovakia the state aid may be equal to maximum of $25 \%$ of the investment, for Eastern and Central Slovakia it is $35 \%$. 
There is no legal right to any investment aid. The applicant must submit an application for investment aid to the competent authorities (ie the Ministry of Economy and other relevant aid providers) who will verify compliance with the general and special conditions under the Investment Assistance Act. The competent authority shall examine the completeness of the investment plan and the general conditions for the provision of investment aid and, if the investment plan contains all the required data, shall ensure that the expert opinion of the investment plan is drawn up. Subsequently, the offer for investment aid is issued to the successful applicant. After receiving the investment offer, the investor must submit an investment application for assistance to the Slovak Government for approval. The application for investment aid is submitted to the Slovak Government for approval. If the project's capital expenditures and the required investment aid exceed certain thresholds, the European Commission's approval is also required.

Investment incentives provided within the framework of adopted EU regulation are recognised as not-violating from the perspective of competition despite theoretically being not in line with basic market principles, but at the same time they are indispensable for attracting FDI, which serves to push the economy ahead, especially for small economies such as Slovakia. In total, 197 investment incentives were awarded by the Ministry of the Economy $(\mathrm{MoE})$ in the form of job creation allowances, retraining allowance, tax relief and in the form of transfer of assets at a price below the market price of a total of $€ 1,818.4$ million, to bring about 48,903,000 new jobs. In the MoE statistics, aid for Jaguar - Land Rover in the Nitra Region is not yet included, totaling $€ 130$ million. We can see that investment incentives as a tool are relatively expensive and with unclear results in some situations, but in many cases the maximum of the incentives provided is not exhausted or used, and sometimes the investment will not even take place. Despite the possible support from the Slovak government not all foreign investors are applying for investment incentives, nor are at any contact with the government during their investment phase.

Investment incentives should mainly serve to support weaker regions, but as can be seen in Table 1, the aid was historically directed to more developed regions mostly based on the localisation decisions by the investors themselves, only recently the least developed regions are attracting more of their attention. Most of the incentives went to the Trenčín Region, amounting to€ 397 million, then the Žilina Region earned a total of $€ 364.7$ million and should bring a total of 6.785 jobs and in the ratio of $€ 53.750$ per capita means most of all regions. Thanks to the automotive industry, most incentives were allocated to the Zilina Region and Trnava, where the newest jobs were planned, amounting to $€ 1,612,000$, and, which in the amount of $€ 19.083$ per capita was the cheapest. The difference between the East and the West is again significant when the aid to the Banska Bystrica region was $€$ 140.6 million and the least amount of state aid went to the Prešov Region, and it totally only $€ 78.7$ million and should bring only 2.576 jobs.

Table 1. Regional distribution of investment incentives in 2002-2017

\begin{tabular}{|c|c|c|c|c|}
\hline Region/County & $\begin{array}{c}\text { Number of } \\
\text { incentives }\end{array}$ & $\begin{array}{c}\text { Volume } \\
\text { (million } € \text { ) }\end{array}$ & Jobs created & $\begin{array}{c}\text { Incentive } \\
\text { per created } \\
\text { work place }\end{array}$ \\
\hline Bratislava & 8 & 355,9 & 7.158 & 49.720 \\
\hline Trnava & 31 & 221,6 & 11.612 & 19.083 \\
\hline Trenčin & 15 & 397 & 7.429 & 53.441 \\
\hline Nitra & 30 & 259,9 & 9.033 & 28.772 \\
\hline Banská Bystica & 30 & 140,6 & 6.886 & 20.418 \\
\hline Žilina & 24 & 364,7 & 6.785 & 53.750 \\
\hline Prešov & 16 & 78,7 & 2.576 & 30.551 \\
\hline Košice & 43 & 262,6 & 10.915 & 24.058 \\
\hline
\end{tabular}

Source: Own processing according to $M H S R$ data 
These differences were influenced by the Investment Assistance Act 561/2007, which was amended 5 times by 2016 and revised 10 times altogether. Law No 231/1999 on state aid, which was also amended many times, was replaced by Act 358/2015. Last change in these laws were done this year via amendment by Act 57/2018 that introduced several changes into the process of granting state aid in Slovak republic. Nevertheless, these adjustments did not produce the desired effect in supporting weaker regions when the Prešov Region again gained only 2 incentives in 2017 in the amount of $€ 19.9$ million in the ratio of $€ 42.315$ per capita, which was relatively the most expensive state aid. Improvements are not significant in the case of Banska Bystrica region when it has gained a total of $€ 9.04$ million and this aid should have only 315 new jobs. There is a special Act 336/2015 on the support of the least developed districts which helped to develop investment opportunities for foreign investors. In 2018 there were some investment incentives which supported project of investors in least developed ares of Slovakia.

In 2017, State aid was split between two supported sections, according to SK NACE categorization. Most of the investment aid was heading to support industrial production. In this area creation 2.982 of jobs (98\%) was supported and the same percentage overall state aid of $€$ 82.465.096. Other mostly supported areas were professional, scientific and technical activities, under which only $2 \%$ of new jobs were supported (74) and of the same level was the total state aid of $€ 1.480 .424$. Up to $67 \%$ of supported businesses have requested aid for enlargement already existing production. Production exports higher than $90 \%$ are expected in almost a year $70 \%$ of supported investments. 27\% of supported investments are owned by Slovakia. In case of the EU countries is $53 \%$ and the remaining $20 \%$, it represents owners from Asia.

\section{Conclusions}

Investment incentives in Slovakia started to be provided after 2000, as previously there was no special legislation that would regulate investment incentives. In institutional terms, state aid respectively. investment incentives cover the State Aid Office. After accession to the EU that power has passed after the abolition of the office to the Ministry of Economy of Slovak republic and other ministries that are providers of aid. Regarding the institutional framework for support of foreign direct investment, the three main institutions are the Ministry of Economy, the Slovak Agency for Development of Investments and Trade (SARIO) and the Regional Development Agencies. MoE SR seeks to increase the inflow of investments into prospective sectors, notably in sectors with higher value added and cost-oriented industries, as well as the direction of investment in less developed regions with high unemployment rates. The aim of MoE SR is to give priority to indirect forms of support that do not have an immediate impact on public finances and create the prerequisite for long-term investment of the region.

Despite the views on investment incentives and their impact on the business environment, in Slovakia they still are a necessary tool for stimulating of job creation and regulating the inflow of foreign investors in Slovak regions. The Slovak government must necessarily regulate their deployment in order to reduce regional disparities between regions. The positive impact of the new investment should be reflected in the creation of new jobs, opportunities for graduate employment, and the creation of new entrepreneurial opportunities for local companies.

\section{Acknowledgements}

The paper is the output of an international scientific project IGA no. 2/2018 - M „Problems and Suggestions - Comparison of Commercial Enviroment between China - Slovakia and Facilitation of Trade and Investment". (Funder: VSEMvs IGA VSEMvs, i.e. School of Economics and Management in Public Administration) 


\section{References}

Belanova, K. (2014, January). Kvalita podnikatelskeho prostredia v krajinách Vysehradskej stvorky a osobitnym akcentom na dostupnost financnych zdrojov [Quality of the business environment in the Vysehrad countries and special emphasis on the availability of financial resources] Biatec. Retrieved from http://www.nbs.sk/_img/Documents/_PUBLIK_NBS_FSR/Biatec/Rok2014/01-2014/03_biatec141_belanova.pdf (in Slovak).

Bevan, A., \& Estrin, S. (2000, October). The Determinants of Foreign Direct Investment in Transition Economies. Centre for New and Emerging Markets, London $\quad$ Business School $\quad 2001 . \quad$ Retrieved http://deepblue.lib.umich.edu/bitstream/handle/2027.42/39726/wp342.pdf?sequence=3

Bevan, A., Estrin, S., \& Meyer, K. (2004, February). Foreign investment location and institutional development in transition economies. International Business Review, 13(1), 43-64. Retrieved from http://www.sciencedirect.com/science/article/pii/S0969593103001082

Brakman, S., Garretsen, H. (2008). Foreign direct investment and the multinational enterprise. Association for evolutionary economics. Retrieved from http://mitpress.mit.edu/sites/default/files/titles/content/9780262026451_sch_0001.pdf

Cheba, K., \& Szopik-Depczyńska, K. (2017). Multidimensional comparative analysis of the competitive capacity of the European Union countries and geographical regions. Oeconomia Copernicana, 8(4), 487-504. https://doi.org/10.24136/oc.v8i4.30

Dudas, T. (2004, March). Stav politickeho prostredia ako faktor investicnej atraktivnosti v statoch strednej a vychodnej Europy [The state of the political environment as a factor of investment attractiveness in the states of Central and Eastern Europe. Journal of Intenational Relations], 2(2), 68-74. Retrieved from http://econpapers.repec.org/-article/brvjournl/v_3a2_3ay_3a2004_3ai_3a2_3ap_3a68-74.htm (in Slovak).

Dudas, T. (2010). Priame zahranicne investicie v slovenskej ekonomike [Direct foreign investment in the Slovak economy]. Bratislava: Vydavatelstvo EKONOM (in Slovak).

Dunning, J. H. (1979, November). Explaining changing patterns of international production: in defence of the eclectic theory. Oxford Bulletin of Economics and Statistics, 41(4), 269-295. https://doi.org/10.1111/j.1468-0084.1979.mp41004003.x

Dunning, J. H. (2001, March). The Eclectic (OLI) Paradigm of International Production: Past, Present and Future. International Journal of the Economics of Business, 8(2), 173-190. https://doi.org/10.1080/13571510110051441

Fabus, M. (2014, November). Foreign direct investment and its impact on the Slovak Republic's economy. Economic Annals-XXI, 9-10(1), 42-45. Retrieved from http://soskin.info/userfiles/file/2014/9-10_2014/1/Fabus.pdf

Fabus, M. (2011, March). Priame zahranicne investicie a ich vplyv pocas hospodarskej krizy [Direct foreign investment and its impact during the economic crisis]. Economics and Business, 1, 147-154. Retrieved from http://www.pauenrouni.com/sk/pevs/casopisy/vedeckycasopis-fep/ (in Slovak)

Fabus, M. (2012, March). Vyuzitie korelacnej analyzy pri skumaniza vislosti prilevu PZI a hospodarskeho rastu na urovniregionov Slovenska [Use of correlation analysis in the determination of FDI inflow and economic growth in the Slovak Republic]. Economics and Business, 2, 23-30. Retrieved from http://www.pauenrouni.com/sk/pevs/casopisy/... (in Slovak)

Fabus, M., \& Prno, I. (2014). Investicie a inovacie v podnikani. [Investment and innovation in business Vysoka skola ekonomie a manazmentu verejnej spravy] (in Slovak).

Ferencikova, S., \& Dudas, T. (2005, April). Vplyv prilevu priamych zahranicnych investícii na hospodarsky rast v novych clenskych statoch Europskej unie zo strednej a vychodnej Europy [Impact of the attribution of foreign direct investment on economic growth in the new member states of the European Union from Central and Eastern Europe]. Journal of Economics, 53(3), 261-272. Retrieved from http://www.sav.sk/index.php?lang=sk\&charset=\&doc=journal-list\&part=list_articles\&journal_issue_no=1175 (in Slovak)

Gozora, V. et al. (2013). Regionalne disparity v malom a strednom podnikani. Riesenie regionalnych disparit [Regional disparities in small and medium-sized enterprises. Renewal of regional disparities]. Bratislava: Vydavatelstvo Merkury (in Slovak). 
The International Journal

ENTREPRENEURSHIP AND SUSTAINABILITY ISSUES

ISSN 2345-0282 (online) http://jssidoi.org/jesi/

2018 Volume 6 Number 2 (December)

http://doi.org/10.9770/jesi.2018.6.2(1)

Hindls, R. et al. (2007). Statistics for Economists. Praha: Professional Publishing (in Czech).

Korauš, A.; Mazák, M.; Dobrovič, J. 2018. Quantitative analysis of the competitiveness of Benelux countries. Entrepreneurship and Sustainability Issues, 5(4), 1069-1083. https://doi.org/10.9770/jesi.2018.5.4(26)

Korcsmáros, E., \& Šimova, M. (2018). Factors affecting the business environment of SMEs in Nitra region in Slovakia. Oeconomia Copernicana, 9(2), 309-331. https://doi.org/10.24136/oc.2018.016

Nazarczuk, J., \& Krajewska, A. (2018). Local determinants of foreign direct investment in Poland: the role of relative distance. Equilibrium. Quarterly Journal of Economics and Economic Policy, 13(1), 73-88. https://doi.org/10.24136/eq.2018.004

Pietrucha, J., Żelazny, R., Kozłowska, M., \& Sojka, O. (2018). Import and FDI as channels of international TFP spillovers. Equilibrium. Quarterly Journal of Economics and Economic Policy, 13(1), 55-72. https://doi.org/10.24136/eq.2018.003

Tancosova, J., \& Svecova, S. (2012, March). Investment attractiveness in the SR and the effect on foreign investors. Elektronicky zbornik vedeckych stati a posterov (pp. 1484-1488). Gyongyos: Karoly Robert Foiskola (in Slovak).

Tancosova, J. (2013, September). Foreign direct investments and their influence on the economic development of Slovakia. Economic Annals-XXI, 3-4(1), 31-34. Retrieved from http://soskin.info/ea/2013/3-4/zmist.html

Tancosova, J. (2014, March). Investment attractiveness of Slovak republic and its determinants. Economic Annals-XXI, 3-4(1), 8-11. Retrieved from http://soskin.info/userfiles/file/2014/3-4_2014/1/Tancosova.pdf

Tancosova, J., \& Cornejova Aradyova, A. (2007, September). Kvalita podnikatelskeho prostredia ako determinant investicnej atraktivnosti ekonomik na prikladestatov [Quality of the business environment as a determinant of the investment attractiveness of the economies on the examples] V4. Economy and Management, III(3), 59-70. Retrieved from https://www.vsemvs.sk/enus/vedaav\%C3\%BDskum/vedeck\%C3\%BD\%C4\%8Dasopis/2007.aspx (in Slovak)

Tvaronavičienè, M. (2018). Toward efficient policy making: forecasts of vulnerability to external global threats, Journal of Security and Sustainability Issues, 7(3), 591-600. https://doi.org/10.9770/jssi.2018.7.3(18)

Ministry of Economics of the Slovak Republic (Official website). Statistical Data. Retrieved from www.economy.gov.sk (in Slovak)

Ministry of Finance of the Slovak Republic (Official website). Statistical Data. Retrieved from www.finance.gov.sk (in Slovak)

Statistical Office of Slovak Republic (Official website). Statistical Data. Retrieved from http://portal.statistics.sk

UNCTAD (Official website). Statistical Data. Retrieved from http://www.unctad.org

Michal FABUS PhD. in International Economics Relations, obtained at University of Economics in Bratislava, currently at Department of Economics and Finance as Head of department, School of Economics and Management in Public Administration in Bratislava (VSEMvs), Slovakia.

ORCID ID: orcid.org/0000-0002-3792-179X

Marek CSABAY, PhD. in International Relations, obtained at University of Economics in Bratislava, currently at Faculty of Economics and Business, Paneuropean University, Bratislava, Slovakia

ORCID ID: orcid.org/0000-0001-6693-7750

Copyright (C) 2018 by author(s) and VsI Entrepreneurship and Sustainability Center

This work is licensed under the Creative Commons Attribution International License (CC BY).

http://creativecommons.org/licenses/by/4.0/

(c) (i) Open Access 